\title{
THE EDUCATIONAL VALUE OF A TRAVELING MUSEUM
}

\author{
Cathy Mowrer \\ Marietta College
}

Some people call it a traveling museum. Others refer to it as a living or open-air museum. Built in Brazil in time to celebrate the quincentennial of Columbus' first voyage to the New World, the Nina, a Columbus era replica ship, provides visitors with a true visual of the size and sailing implements of Columbus' favorite ship from over 500 years ago. Indeed, builders erected this fully functioning sailing caravel using only tools that were available to shipwrights in Columbus' time. Thus, visitors on this ship will feel more like they have stepped back in time rather than into a museum exhibit.

I joined the crew of the Nina in Gulf Shores, Alabama, at the beginning of February 2013. As part of a sabbatical project, my goal was to document my days aboard the ship in a blog. I soon found that my shipboard duties took up most of my day and blogging was relegated to whenever I had a spare moment. Keeping up with my blog quickly became less of a concern as I became more involved in conducting tours. I quickly realized that I gained the most valuable insights as an educator when I observed or gave tours to school-age children. I was pleased to see the students become active participants in their learning process. This helped substantiate the belief that I have always held that students stay interested, ask better questions, and engage in higher order thinking tasks when they are actively engaged in the learning process.

At the beginning of each tour, I told students that they were going to take a journey back in time and immediately tried to sign them on as part of Columbus' crew in 1492. It would not be an easy voyage. A sailor's existence in the middle of the sea in the late fifteenth century was physically exhausting and often lonely. We discussed

- saying goodbye to their parents.

- the meager amount of pay they would earn, if any.

- working long hours in all kinds of weather.

- sleeping and eating on deck in four-hour shifts.

- being the only crew allowed below deck, and then only to take care of the animals.

- having only one set of clothes that were torn, dirty, and sticky from the black pine tar that was used as a wood preservative.

- not having bathroom facilities and having to use the railing of the bow of the ship for that necessity.

- moving the levers on the windlass to lift the heaviest anchors, using old seafaring technology.

A life at sea lost some of its glamour at this point, but the students and teachers were fascinated to hear about the voyages of Columbus and the role that the Nina played in this important moment in history. 
This field-trip tour of the Nina is hands-on learning at its best. In this setting, students could touch the line, pass around a ballast stone, and move the extremely large tiller that steered the ships in Columbus' day. (The steering wheel did not appear until the early $1700 \mathrm{~s}$.) The windlass was a necessary tool on board the ships Columbus sailed and students soon came to understand the labor involved in using it to raise and lower anchors, animals, and the shoreboat. Since most crewmembers in the early days of exploration were illiterate, a short lesson was given on how to use a traverse board to record speeds and distances. Students were also allowed to examine the quadrant to see how early explorers determined their latitude. Walking around the deck of the ship, students were quick to point out the barrels that were filled with nuts and other nonperishable food. Discussions then took place in regard to what food and drink were available and how it was cooked on board a ship. This led to further questions about the purpose of the animals that were brought on board. What types of animals were kept in the hold? Who was responsible for their care? When someone raised the question of how they were brought up, students were once again led to the windlass and another group would begin the process of moving the windlass with the idea that a large animal was being hoisted in or out of the hold.

I continued the tour of the ship by pointing out the different parts of the ship and the appropriate name that the students should call it by. Students often erupted into laughter at the first mention of the "poop deck." I then would explain the superstitious nature of many of the crewmembers and that the carved dolls they attached to the top deck were meant to ward off evil. A further explanation of the origination of the term pupa as the Latin word meaning doll brought nods and aha's to their smiling faces. By the end of the tour, students were having conversations in which they discussed the masts, hold, tiller, and other navigational equipment. Experiencing this traveling museum as a crewmember opened up the world of Christopher Columbus to the students. It made the factoids meaningful and aided in making sense of the events that we want our students to understand.

The voyages of Christopher Columbus are among the most studied events in American and world history, and students cover this subject matter at almost every grade level. The very youngest of students learned that Columbus sailed on the Nina Pinta, and Santa Maria and "discovered" a New World in 1492. Those in middle school are taught that there were other explorers who made their way to the Americas before Columbus, while older students begin to delve critically into the motivations behind many of the decisions that Columbus and his financial backers made, as well as the consequences of settling this uncharted land. Even looking at the controversial issues that surround Columbus and the colonization of the Americas, one cannot dismiss his place in history and the importance of those voyages. Nowhere can one get a better feel for what life was like for a young sailor on those early journeys than to step aboard a replica ship. This is the value of visiting and experiencing these traveling museums. 
The replica ship that I sailed on is by no means the only example of a traveling museum available to the public. There are also replica ships that provide students with life-size examples of service on board a ship during other historical periods. A visit to Jamestown Settlement allows visitors to board three re-creations of the ships that brought the first settlers from England to Virginia in the early 1600s. Historical interpreters, dressed in period garb, give tours of the Susan Constant, Godspeed, and Discovery. These interpreters often portray a character that would have lived and worked during that time period. Students touring these ships are encouraged to interact with the interpreters in order to grasp a better understanding of the daily life of the people who worked and traveled on these ships. Participating in hands-on activities while aboard the ships enhances the educational experiences as well as to entertain the visitors.

While the replica ships that the Columbus Foundation owns are well described as traveling museums, there are many other replicas that are docked in other cities as permanent exhibits. However, the costs of maintaining these ships has become problematic in keeping the ships open for tours. Replicas of the Pinta and Santa Maria are docked outside the Corpus Christi Museum of Science and History. Sadly, due to high maintenance costs, these ships soon will be demolished and the scraps will be used to maintain the replica ship, Nina, also docked at the museum. The city of Columbus, Ohio, has a Santa Maria Museum that was built in 1991 to celebrate the quincentennial of Columbus' first voyage in 1492 . This floating museum is currently closed while supporters raise funds to continue its mission of providing educational tours and programs.

Educational experiences on floating museums are not relegated to replica ships only. The USS Constitution is an original military frigate built in 1797. This ship served with distinction in several wars, earning the name "Old Ironsides." Going through a major restoration in the 1920 s, funded mostly by young students in a "pennies campaign," the USS Constitution traveled more than 22,000 miles throughout the 1930s. It is now docked in the Charleston Navy Yard at the end of the Boston Freedom Trail. Noted for being the world's oldest commissioned warship afloat, the USS Constitution is preserved as a floating museum. Visitors are given free tours conducted by active duty military personnel. Educator packets are available for teachers that include a thematic unit, DVD, and posters. Schools can sign up for planned tours that allow students to take part in interactive programs in which they assume roles, don costumes, and interact with navigational equipment. These programs are in addition to the normal visitor tour and therefore have a fee attached.

Sadly, I have found that most public schools cannot schedule such tours for students. Budget cuts have forced many school districts to eliminate field trips from the school curriculum, especially those with an admission fee. Private schools and homeschooling organizations might take advantage of programs like the ones the Nina and USS Constitution offer, but most children attending public schools are not privy to such valuable educational experiences anymore. Fortunately, some museums are 
applying for grants that provide special curriculum funding for schools in lower socioeconomic areas. Other alternatives include taking virtual tours, where available, or contacting the museum for educator packets that include DVDs, activity ideas, photos, maps, and more.

Virtual tours have become a popular means of sharing information about replica ships. These tours, via the Internet, allow students to visit replica ships within the confines of the classroom. An example of this can be seen at the website for the replica ship of the HMS Endeavor, the vessel that Lieutenant James Cook commanded on voyages to New Zealand and Australia during the mid-1700s. Introduced as a virtual excursion, this tour is led by a cartoon character named Midshipman Jonathan Munkhouse. An audio component provides students with narration about different parts of the ship as well as an explanation of life on board a sailing bark during this time period. This tour is designed to educate and entertain by mixing real photos of the replica ship with animated portions. Activities are provided but they tend to be more like worksheets rather than engaging and thought provoking. There are limited instructional resources, but teaching notes are available on the site. Virtual tours, like that for the HMS Endeavor replica ship, provide opportunities for students to view museums that they would not, otherwise, have an opportunity to visit. What is not available with this type of tour is the face-to-face interaction with a tour guide who can answer questions and the hands-on component of being able to manipulate the nautical equipment. Also, many Internet sites are not easy to maneuver and technical difficulties arise when links fail to work properly. It is imperative that teachers preview the sites for content and ease of use before allowing students to view a virtual tour.

While serving on board the Nina I was known as a crewmember, but I feel as if I was an educator at my very best. The journey that I took the students on during that brief time on the deck of the replica ship opened up their minds to whatever relevant content their teachers already had covered or wanted to cover once they were back in the classroom. Those educators that prepared students for the ship's tour by providing background knowledge on Columbus and his voyages had equipped students to make connections to the new information they learned on board. Thus, questions about the difference between first and subsequent voyages were common. How did life change on board when additional crew were added? Did the crew begin using hammocks after observing them being used by the "Indians"? How did celestial navigation guide the voyages? What was it about the size and construction of the Nina that allowed it to be the only ship in a large fleet to survive a 1495 hurricane? These questions and others like them provoked discussions that promoted higher order thinking skills that educators strive for in the classroom. These discussions further encouraged critical thinking by being able to demonstrate the use of navigational equipment, show where hammocks would have been set up, and compare the four-masted Nina with other larger ships of that time.

Museums are becoming increasingly more interactive. Passivelearning is giving way to the more active learner who makes personal connections with the exhibits and 
wants to touch, move, climb, taste, and explore the surroundings of the museum. My time as a crewmember on a traveling museum confirmed my belief that engaging, hands-on experiences can provide a solid foundation for subsequent learning. I believe that many students went home after their tour on the Nina to explain to their parents not only what life was like in Columbus' day but also to question whether there are still New Worlds out there to be explored, where they might be and how we might get there, and whether they should be explored. I believe the students who boarded the Nina came as passive learners. They left as bold explorers. 